\title{
New particle formation events in semi-clean South African savannah
}

\author{
V. Vakkari ${ }^{1}$, H. Laakso ${ }^{1}$, M. Kulmala ${ }^{1}$, A. Laaksonen ${ }^{2,3}$, D. Mabaso ${ }^{4}$, M. Molefe ${ }^{5}$, N. Kgabi ${ }^{5}$, and L. Laakso ${ }^{1,2,6}$ \\ ${ }^{1}$ Department of Physics, University of Helsinki, P. O. BOX 64, 00014 University of Helsinki, Finland \\ ${ }^{2}$ Finnish Meteorological Institute, P. O. BOX 503, 00101 Helsinki, Finland \\ ${ }^{3}$ Department of Applied Physics, University of Eastern Finland, Kuopio 70211, Finland \\ ${ }^{4}$ Rustenburg Local Municipality, Rustenburg, Republic of South Africa \\ ${ }^{5}$ Department of Physics, North-West University, Private Bag X 2046, Mmabatho, Republic of South Africa \\ ${ }^{6}$ School of Physical and Chemical Sciences, North-West University, Potchefstroom, Republic of South Africa
}

Received: 5 November 2010 - Published in Atmos. Chem. Phys. Discuss.: 17 December 2010

Revised: 16 March 2011 - Accepted: 1 April 2011 - Published: 7 April 2011

\begin{abstract}
This study is based on 18 months (20 July 2006-5 February 2008) of continuous measurements of aerosol particle size distributions, air ion size distributions, trace gas concentrations and basic meteorology in a semi-clean savannah environment in Republic of South Africa. New particle formation and growth was observed on $69 \%$ of the days and bursts of non-growing ions/sub-10 nm particles on additional $14 \%$ of the days. This new particle formation frequency is the highest reported from boundary layer so far. Also the new particle formation and growth rates were among the highest reported in the literature for continental boundary layer locations; median $10 \mathrm{~nm}$ formation rate was $2.2 \mathrm{~cm}^{-3} \mathrm{~s}^{-1}$ and median $10-30 \mathrm{~nm}$ growth rate $8.9 \mathrm{~nm} \mathrm{~h}^{-1}$. The median $2 \mathrm{~nm}$ ion formation rate was $0.5 \mathrm{~cm}^{-3} \mathrm{~s}^{-1}$ and the median ion growth rates were $6.2,8.0$ and $8.1 \mathrm{~nm} \mathrm{~h}^{-1}$ for size ranges $1.5-3 \mathrm{~nm}, 3-7 \mathrm{~nm}$ and $7-20 \mathrm{~nm}$, respectively. The growth rates had a clear seasonal dependency with minimum during winter and maxima in spring and late summer. The relative contribution of estimated sulphuric acid to the growth rate was decreasing with increasing particle size and could explain more than $20 \%$ of the observed growth rate only for the $1.5-3 \mathrm{~nm}$ size range. Also the air mass history analysis indicated the highest formation and growth rates to be associated with the area of highest VOC (Volatile Organic Compounds) emissions following from biological activity rather than the highest estimated sulphuric acid concentrations. The frequency of new particle formation, however, increased nearly monotonously with the estimated sulphuric acid reaching $100 \%$ at $\mathrm{H}_{2} \mathrm{SO}_{4}$ concentration of $6 \cdot 10^{7} \mathrm{~cm}^{-3}$, which suggests the formation and growth to be independent of each other.
\end{abstract}

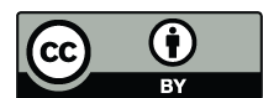

Correspondence to: V. Vakkari (ville.vakkari@helsinki.fi)

\section{Introduction}

The aerosol particles affect the radiation budget in two ways: directly by scattering the solar radiation and indirectly via acting as cloud condensation nuclei and therefore modulating the properties of the clouds. Besides that aerosol particles affect significantly also human health and visibility in urban areas (Pope and Dockery, 2006; Hand and Malm, 2007; Anderson, 2009). Actually the largest current uncertainties in the anthropogenic changes in the Earth radiation budget arise from aerosols - the uncertainty in the total aerosol effect on earth radiative forcing is larger than the combined effect of the long-lived greenhouse gases $\mathrm{CO}_{2}$ and methane (Forster et al., 2007).

To reduce the uncertainty of the aerosol effects on global radiation budget, measurements of the atmospheric aerosols have to be conducted globally, because the aerosol population in the atmosphere is largely inhomogeneous due to the relatively short atmospheric lifetime of the aerosol particles. Therefore regional conditions, as well as seasonal changes in the regional conditions, have a large effect on processes which affect the regional aerosol properties.

The concentrations of climatically important aerosol particles depend on their different sources and sinks. The sources of the aerosol particles in the size range where they can effectively contribute to the direct or indirect radiative effect include primary emissions from natural processes, anthropogenic primary emissions and new particle formation from gaseous compounds in the atmosphere, which has been observed in a variety of environments around the globe (Kulmala et al., 2004). The importance of new particle formation to the global aerosol number and cloud condensation nuclei budgets has also been confirmed by global models (Spracklen et al., 2008; Merikanto et al., 2009).

Published by Copernicus Publications on behalf of the European Geosciences Union. 
Although the need is evident, there is only a limited amount of aerosol observations from Africa (Swap et al., 2003) and other less developed areas (Laakso et al., 2006). Conversely, the number of long-term continuous measurements of aerosol particle properties in Europe and North America are increasing (e.g. Kulmala and Kerminen, 2008 and references therein; Iida et al., 2008; Venzac et al., 2009; Manninen et al., 2010).

The only reported observations of new particle formation and growth from continental Africa so far are by Laakso et al. (2008), who gave an overview of the first complete year of the measurements in Botsalano game reserve in North-West province in Republic of South Africa. Laakso et al. (2008) reported new particle formation to take place on almost every sunny day with formation and growth rates among the highest observed in continental environments. Therefore the paper concluded that new particle formation in savannah environment is likely to have a regional effect on cloud condensation nucleus budget and on the properties of the clouds.

In this study, supporting the EUCAARI project's South African component (Kulmala et al., 2009), we provide a more detailed analysis and an extension on the new particle formation observed at Botsalano (Laakso et al., 2008). The measurements utilized in this study are for the period 20 July 2006-5 February 2008 with the main focus being on aerosol particle and air ion formation and growth rates. The seasonal variation of the formation and growth rates is studied and, in order to understand the processes behind the observations, the measurements are combined with air mass history analysis, ion recombination calculations and estimates of sulphuric acid concentrations using a recently developed proxy (Petäjä et al., 2009).

\section{Measurements}

\subsection{Measurement location}

The measurements for this study were conducted in Botsalano game reserve (Laakso et al., 2008), latitude $25.54^{\circ} \mathrm{S}$, longitude $25.75^{\circ} \mathrm{E}, 1400 \mathrm{~m}$ a.s.l., from 20 July 2006 until 5 February 2008.

Botsalano game reserve is located in the North-West Territory of the Republic of South Africa, Fig. 1, $10 \mathrm{~km}$ from the border of Botswana and $50 \mathrm{~km}$ from the nearest towns, Mafikeng, population 260000 , in the south and Zeerust, population 140000 , in the east. Gaborone, population 200000 , capital of Botswana, lies $100 \mathrm{~km}$ north of the measurement site and Rustenburg, population $400000,150 \mathrm{~km}$ east of the site.

The region east of Botsalano is quite sparsely populated next to the game reserve, but has heavy industry in the Rustenburg area. Rustenburg is considered as one of the large regional pollution sources in the North-West province (Piketh et al., 2005; Laakso et al., 2008) due to its large plat-

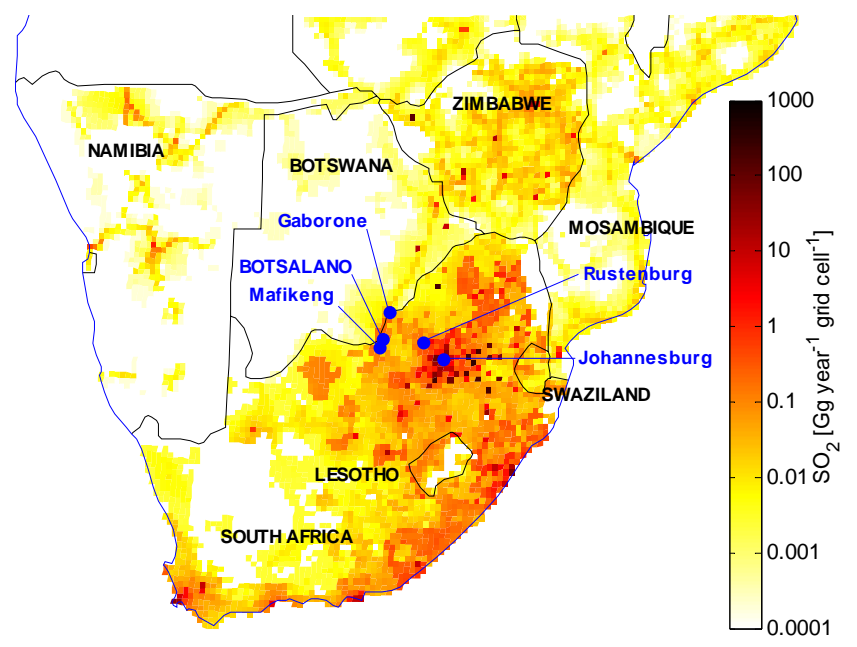

Fig. 1. Location of Botsalano game reserve and SAFARI 2000 $\mathrm{SO}_{2}$ emission inventory (Fleming and van der Merwe, 2002). The resolution of the emission inventory is $20 \mathrm{~km} \times 20 \mathrm{~km}$.

inum group metal mines and refineries. Other major sources in the east impacting the measurement site are the megacity of Johannesburg approximately $220 \mathrm{~km}$ east with more than 10 million inhabitants, and especially the industrialized Highveld area southeast of Johannesburg with high emissions from coal-based power plants and petrochemical industry.

The region west and south of Botsalano on the Botswana side and the Karoo region in western and central South Africa have little industrial or other anthropogenic activities and form the clean sector. In this sector also biological activity is lower as the landscape is mainly semi-arid shrublands (Friedl et al., 2002). In addition to industrial sources, the site is affected by emissions from regular wild fires during the dry season (June-October). The major fires are in the north; however, fires may take place in any direction from the site.

\subsection{Instrumentation}

The mobile measurement trailer and the instrumentation in the trailer are described in detail by Petäjä et al. (2010). In this study we utilize aerosol particle size distributions from the differential mobility particle sizer (DMPS) (Hoppel, 1978; Jokinen and Mäkelä, 1997), size range 10-840 nm, air ion size distributions from the air ion spectrometer (AIS) (Mirme et al., 2007), size range $0.8-42 \mathrm{~nm}$, sulphur dioxide concentration from the Thermo $42 \mathrm{~S}$ analyser (Thermo Environmental Instruments Inc., 1992) and the basic meteorological quantities including solar radiation from the photosynthetically active radiation (PAR) sensor (LiCor LI-190SB). 


\section{Methods}

\subsection{New particle formation classification}

New particle formation events were determined in the DMPS measurements along the guidelines set in Dal Maso et al. (2005). The aerosol particle size distribution data from the DMPS measurements were divided in new particle formation or "event days", "non-event days", when no new particles were formed and "undefined days", when it was not possible to determine with complete certainty whether there was new particle formation or not.

To classify a day as a new particle formation day, new particles were required to appear in the size range smaller than $25 \mathrm{~nm}$ and the new mode was required to grow in mean diameter. These days were further divided into three subcategories IA, IB and II, depending on how smooth the size distribution was. For the classes IA and IB it was possible to calculate formation and growth rates from the measurements, whereas for class II determination of one or the other was not possible due for instance to gaps or fluctuations in the size distribution.

New particle formation was determined from the ion spectra obtained from AIS measurements according to the classification presented by Yli-Juuti et al. (2009). The five main classes, see above, were the same for ions and aerosol particle spectra from the DMPS, but in addition four more classes were defined to describe some characteristics typical for the ion spectrum but not seen in DMPS. These extra classes belong to the undefined category in the DMPS aerosol particle classification. The detailed new particle formation classification criteria are presented in Table 1.

Ion bursts caused by rain in sizes $1-25 \mathrm{~nm}$ (Hirsikko et al., 2007) were encountered frequently during the wet season and the so called Mixed-type ion bursts throughout the period, but the classes Apple and Hump are included in the study mainly for consistency with earlier studies by Vana et al. (2008) and Yli-Juuti et al. (2009). Days when there were gaps in the data so that they could not reliably be classified in the above classes were classified as bad data and left out from the analysis.

\subsection{Aerosol particle formation and growth rates}

The $10 \mathrm{~nm}$ aerosol particle formation rate - the $10 \mathrm{~nm}$ set by the DMPS detection limit -was determined from DMPS measurements similarly as in Dal Maso et al. (2005), who expressed

$J_{10}=\frac{d N_{10-30}}{d t}+F_{\text {coag }}+F_{\text {growth }}$.

The first term, $\frac{d N_{10-30}}{d t}$, was obtained from a linear fit to the $10-30 \mathrm{~nm}$ particle concentration during the time at the beginning of the new particle formation when the concentration increase is nearly linear. The coagulation loss term, $F_{\text {coag }}$, was calculated according to the formulae given by Dal Maso et al. (2005) and the last term, $F_{\text {growth }}$, representing the losses from particles growing out of the size range, was set to zero, as the $10-30 \mathrm{~nm}$ size range is wide enough so that the particles do not grow past the upper limit of the size range during the period when formation rate is determined.

For the growth rate calculation Dal Maso et al. (2005) used a log-normal size distribution fit to the measured aerosol particle size spectrum to follow the time evolution of the distribution. Now a one to three modal log-normal fit was calculated using a method described in detail by Vartiainen et al. (2007).

The actual growth rate is obtained by tracing the increase of the geometric mean diameter of the log-normally fitted nucleation mode as it grows from 10 to $30 \mathrm{~nm}$ diameter and making a linear fit to the obtained data points. The upper limit for the growth rate calculation was increased from the $25 \mathrm{~nm}$ used by Dal Maso et al. (2005) to $30 \mathrm{~nm}$ because of the high growth rates observed (Laakso et al., 2008). Only the modal peaks above the $10 \mathrm{~nm}$ detection limit of the DMPS were used for calculating the growth rate - fitting a mode when most of the mode is outside the measurement range can lead to ambiguous results.

\subsection{Formation and growth rates of charged particles and ions}

The charged particle and ion formation and growth rates were determined according to Kulmala et al. (2007) and Hirsikko et al. (2005).

The $2 \mathrm{~nm}$ ion formation rate $J_{2}^{ \pm}$obtained from the AIS measurements was calculated according to Kulmala et al. (2007) as

$$
\begin{aligned}
J_{2}^{ \pm} & =\frac{d N^{ \pm}}{d t}+\mathrm{CoagS}_{2-3} \cdot N^{ \pm}+\frac{\mathrm{GR}^{ \pm}}{3 \mathrm{~nm}-2 \mathrm{~nm}} \cdot N^{ \pm} \\
& +\alpha \cdot N^{ \pm} \cdot N^{\mp}-\beta \cdot N \cdot N^{ \pm},
\end{aligned}
$$

where \pm refers to the polarity of the ions. $N^{ \pm}$is the $2-3 \mathrm{~nm}$ ion concentration of respective polarity, $N$ is the concentration of 2-3 nm neutral particles, $\mathrm{CoagS}_{2-3}$ is the coagulation sink for $2-3 \mathrm{~nm}$ particles, $\mathrm{GR}^{ \pm}$is the growth rate of $1.5-3 \mathrm{~nm}$ ions of respective polarity, $\alpha$ is the ion-ion recombination coefficient and $\beta$ is the ion-aerosol recombination coefficient.

The first term, $\frac{d N^{ \pm}}{d t}$, was calculated similarly as for the $10 \mathrm{~nm}$ formation rate, i.e. by a linear fit to the concentration of $2-3 \mathrm{~nm}$ ions. $\mathrm{GR}^{ \pm}$was calculated for the size interval $1.5-3 \mathrm{~nm}$ as described below. For the calculation of $J_{2}^{ \pm} N$ was assumed to be a hundred times the sum of the total 2-3 nm ion concentration $N^{ \pm}$as recent observations from boreal forest suggest (Manninen et al., 2009a). The values for coefficients $\alpha$ and $\beta$ were $1.6 \cdot 10^{-6} \mathrm{~cm}^{3} \mathrm{~s}^{-1}$ and $0.01 \cdot 10^{-6} \mathrm{~cm}^{3} \mathrm{~s}^{-1}$ (Tammet and Kulmala, 2005). The total $2 \mathrm{~nm}$ ion formation rate $J_{2}$ (ions) is the sum of positive and negative ion formation rates. 
Table 1. New particle formation criteria. The ion burst criteria, the four last classes, are reproduced after Yli-Juuti et al. (2009).

\begin{tabular}{|c|c|}
\hline $\begin{array}{l}\text { IA } \\
\text { DMPS and } \\
\text { AIS }\end{array}$ & $\begin{array}{l}\text { New mode with growing mean diameter appears in particle size range smaller than } 25 \mathrm{~nm} \text {. } \\
\text { No or little fluctuation in mode particle number and mean diameter. } \\
\text { Low background concentration, suitable for modelling studies. }\end{array}$ \\
\hline $\begin{array}{l}\text { IB } \\
\text { DMPS and } \\
\text { AIS }\end{array}$ & $\begin{array}{l}\text { New mode with growing mean diameter appears in particle size range smaller than } 25 \mathrm{~nm} \text {. } \\
\text { Possible to calculate growth rate. }\end{array}$ \\
\hline $\begin{array}{l}\text { II } \\
\text { DMPS and } \\
\text { AIS }\end{array}$ & $\begin{array}{l}\text { New mode with growing mean diameter appears in particle size range smaller than } 25 \mathrm{~nm} \text {. } \\
\text { Disturbances in the growth of the new mode or in the data make it impossible to determine growth rate. }\end{array}$ \\
\hline $\begin{array}{l}\text { Non-event } \\
\text { DMPS and } \\
\text { AIS }\end{array}$ & No new particles appear below $25 \mathrm{~nm}$ and no growing Aitken-size mode. \\
\hline $\begin{array}{l}\text { Undefined } \\
\text { DMPS and } \\
\text { AIS }\end{array}$ & $\begin{array}{l}\text { Uncertain days when it cannot be determined with full certainty if there was new particle formation or not. } \\
\text { New particles appear below } 25 \mathrm{~nm} \text { but do not grow. }\end{array}$ \\
\hline $\begin{array}{l}\text { Apple } \\
\text { AIS only }\end{array}$ & $\begin{array}{l}\text { There is a new mode below } 25 \mathrm{~nm} \text { but the mean diameter of the mode does not grow. There is a clear gap } \\
\text { between the new mode and other modes. }\end{array}$ \\
\hline $\begin{array}{l}\text { Hump } \\
\text { AIS only }\end{array}$ & $\begin{array}{l}\text { There is a nucleation burst starting from the cluster mode but the growth does not continue to larger sizes } \\
\text { than } 10 \mathrm{~nm} \text {. }\end{array}$ \\
\hline $\begin{array}{l}\text { Rain } \\
\text { AIS only }\end{array}$ & Rain-induced ion bursts in nucleation mode size range. \\
\hline $\begin{array}{l}\text { Mixed-type } \\
\text { AIS only }\end{array}$ & $\begin{array}{l}\text { There are new particles in the size range smaller than } 25 \mathrm{~nm} \text {. The day does not have features of class I, II, } \\
\text { apple or hump, or it has features of many of these classes. }\end{array}$ \\
\hline
\end{tabular}

The production of neutral 2-3 nm particles from recombination of opposite polarity ions, i.e. ion-ion recombination rate, was calculated similarly as in Manninen et al. (2009b). The recombination rate was calculated for the complete measurement period. For the new particle formation events the ion-ion recombination rate is given as median value during the linear growth of the $2-3 \mathrm{~nm}$ ion concentration, i.e. during the period when the first term in Eq. (2) was calculated. The upper limit of ion induced nucleation was estimated as the sum of the recombination rate and the total ion formation rate $J_{2}$ (ions).

The AIS ion spectra were analysed for the growth rates using the method described by Hirsikko et al. (2005) by following the position of the maximum concentration (in time) for each size channel of the AIS in a size interval. For the ion spectrum three size regions were selected for calculating the growth rate: $1.5-3 \mathrm{~nm}, 3-7 \mathrm{~nm}$ and $7-20 \mathrm{~nm}$. These are commonly used to account for the change of growth rate during the growth of the particles and were used also by Hirsikko et al. (2005).

\subsection{Sulphuric acid proxy}

Sulphuric acid concentration was estimated with a proxy calculated according to Eq. (4) by Petäjä et al. (2009) as

$\mathrm{H}_{2} \mathrm{SO}_{4}$ proxy $=k_{3} \frac{\left[\mathrm{SO}_{2}\right] \cdot \mathrm{Glob}}{\mathrm{CS}}$,

where $\mathrm{SO}_{2}$ is the measured sulphur dioxide concentration in molecules $\mathrm{cm}^{-3}$, Glob is the measured global radiation in $\mathrm{W} \mathrm{m}^{-2}, \mathrm{CS}$ is the condensation sink in $\mathrm{s}^{-1}$ calculated from the aerosol particle size distribution measured with the DMPS (see Dal Maso et al., 2005) and the empirical scaling factor (Petäjä et al., 2009)

$k_{3}=1.4 \cdot 10^{-7} \cdot \mathrm{Glob}^{-0.70}$.

The unit of $k_{3}$ is $\mathrm{m}^{2} \mathrm{~W}^{-1} \mathrm{~s}^{-1}$. This sulphuric acid proxy has been developed based on measurements in boreal forest and thus the absolute values are not necessary valid for southern African conditions. Despite this significant uncertainty, it provides valuable information on the spatial variability and annual cycles of sulphuric acid. 


\subsection{Air mass history}

The air mass history was investigated using back-trajectories. The back-trajectories were calculated using the HYbrid Single-Particle Lagrangian Integrated Trajectory (HYSPLIT) version 4.8 model developed by the National Oceanic and Atmospheric Administration (NOAA) Air Resources Laboratory (ARL) (Draxler and Hess, 2004). The model was run with the GDAS meteorological archive produced by the US National Weather Service's National Centre for Environmental Prediction (NCEP) and archived by ARL (Air Resources Laboratory, 2009). The HYSPLIT model was run for 96-hour back-trajectories at every hour throughout the complete measurement period.

The accuracy of trajectories greatly depends on the quality of the underlying meteorological data in use (Stohl, 1998). The errors accompanying single trajectories are currently estimated as 15 to $30 \%$ of the trajectory distance travelled (Stohl, 1998; Riddle et al., 2006). Studying regional patterns and using a large dataset this accuracy is sufficient.

For the air mass history study a $0.5^{\circ} \times 0.5^{\circ}$ grid was defined over the southern Africa. Each grid cell was then assigned the mean of the observed concentrations at Botsalano for the trajectories passing through that cell. In other words, the value for each grid cell represents the mean concentration observed at Botsalano for all the trajectories passing through this grid cell. A minimum of five trajectories per cell was required for the statistical reliability.

\section{Results}

\subsection{New particle formation and growth rates}

New particle formation and growth was observed on $69 \%$ of the days during the measurement period 20 July 20065 February 2008. In addition to this on $14 \%$ of the days non-growing ion bursts were observed. The non-growing ion bursts refer here to the cases when ions appear in the 2-20 nm regime in the AIS spectrum, but they do not present growth. In Table 1, this means classes apple, hump, rain and mixedtype.

This reanalysis of the data shows lower values than the $90 \%$ new particle formation frequency reported by Laakso et al. (2008), but the new particle formation frequency in Botsalano is still the highest reported from the continental boundary layer so far. On only $6 \%$ of the days there certainly was no new particle formation, which leaves $11 \%$ of the days as undefined. The new particle formation frequency did not have seasonal variation but remained rather constant throughout the measurement period, Fig. 2.

The growth rates determined from the DMPS measurements varied from 2.1 to $30 \mathrm{~nm} \mathrm{~h}^{-1}$ with a mean of $9.7 \mathrm{~nm} \mathrm{~h}^{-1}$ and median $8.9 \mathrm{~nm} \mathrm{~h}^{-1}$. These values are among the highest reported in literature from continental bound-

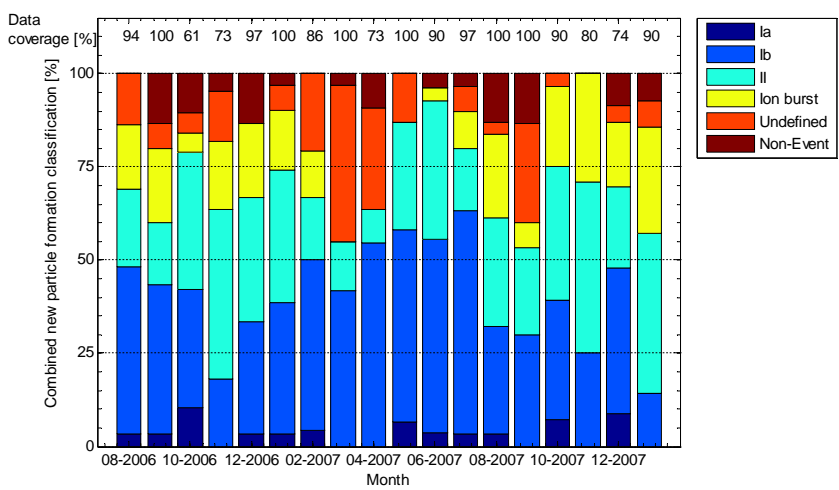

Fig. 2. New particle formation frequency combined from both DMPS and AIS measurements. Classes I and II show clear new particle formation and growth. Ion bursts include all periods when non-growing ions were observed in the $2-25 \mathrm{~nm}$ size range.
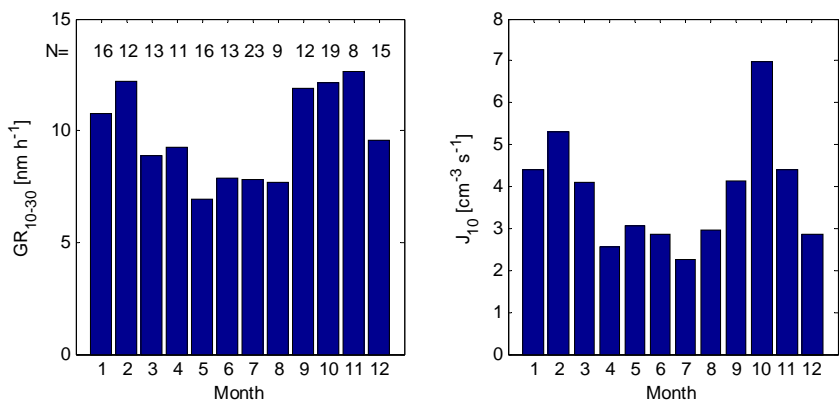

Fig. 3. Annual behaviour of aerosol particle growth and formation rates averaged over 18 months. Number of events analysed for each month is indicated in the left hand side panel.

ary layer, especially for rural locations, where growth rate varies typically from 1 to $10 \mathrm{~nm} \mathrm{~h}^{-1}$ (Kulmala et al., 2004) - in remote areas the growth rates are even lower, from 0.1 to $1 \mathrm{~nm} \mathrm{~h}^{-1}$ (Kulmala et al., 2004; Kulmala and Kerminen, 2008). The growth rates in Botsalano are in fact comparable to observations in polluted urban areas, where growth rates are often higher than $10 \mathrm{~nm} \mathrm{~h}^{-1}$ (Kulmala and Kerminen, 2008) and can reach up to $40 \mathrm{~nm} \mathrm{~h}^{-1}$ (Iida et al., 2008) although Botsalano can be considered neither urban nor polluted.

The annual behaviour of the growth rates is presented in Fig. 3. For January and February the values are averaged over 2007 and 2008 and for July to December over 2006 and 2007. The growth rate clearly peaks in spring and late summer, from September to November and February, and has a minimum in winter, from May to August. This is in accordance with earlier observations from northern hemisphere (e.g. Kulmala et al., 2004; Dal Maso et al., 2005) where the seasonal variation of particle growth rates is explained by changes in biogenic VOC-emissions (e.g. Mäkelä et al., 1997; Dal Maso et al., 2005). In case of southern Africa, the similar annual biogenic emission cycle can be explained 

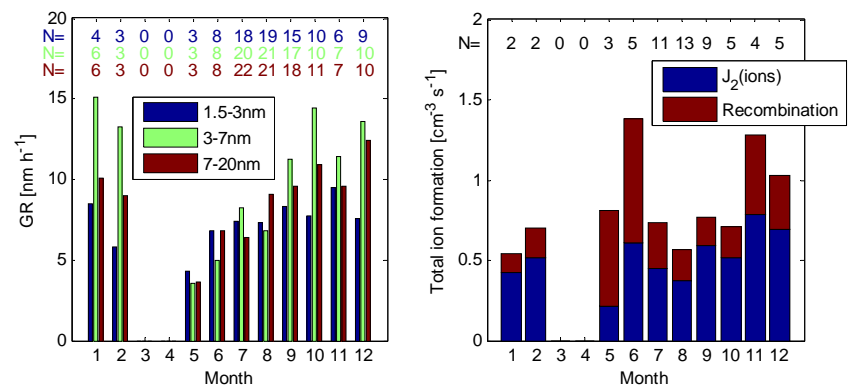

Fig. 4. The left panel of the figure presents the monthly averages of the ion growth rates from the AIS measurements for three size ranges. The growth rates are averaged over both polarities. The right panel presents the ion formation rate $J_{2}$ (ions) and the ion-ion recombination rate, which give an estimate of the upper limit of the ion formation (e.g. Manninen et al., 2009b). The number of events analysed for each month and size range are also shown.

by precipitation pattern and respective changes in vegetation (Otter et al., 2002; Otter et al., 2003; Güenther et al., 1996).

The formation rate of $10 \mathrm{~nm}$ particles, $J_{10}$, from the DMPS measurements varied from 0.1 to $28 \mathrm{~cm}^{-3} \mathrm{~s}^{-1}$ with mean of $3.8 \mathrm{~cm}^{-3} \mathrm{~s}^{-1}$ and median $2.2 \mathrm{~cm}^{-3} \mathrm{~s}^{-1}$. Also $J_{10}$ is in the high end of the aerosol formation rates observed in continental boundary layer, which range typically from 0.01 to $10 \mathrm{~cm}^{-3} \mathrm{~s}^{-1}$ in regional new particle formation events (Kulmala et al., 2004). In polluted locations the formation rates are higher (Kulmala et al., 2004; Shen et al., 2011) and can reach several hundred particles per cubic centimetre per second (Iida et al., 2008).

The annual behaviour of the $J_{10}$ shows peaks in the spring and in the late summer and a minimum during the winter, which is in line with previous observations in Northern Hemisphere (e.g. Dal Maso et al., 2005).

The ion growth rates were determined from the AIS measurements for three size ranges, $1.5-3 \mathrm{~nm}, 3-7 \mathrm{~nm}$ and $7-$ $20 \mathrm{~nm}$. The mean, minimum and maximum values are given in Table 2. Monthly averages of these growth rates are presented in Fig. 4 left panel. The values for each month are averaged over both polarities. The new particle formation was not always as clear in the smallest size range of $1.5-3 \mathrm{~nm}$ as in larger sizes and thus that size range has fewer observations than the larger size ranges. The number of events analysed for GR is presented for each month in the left panel of the Fig. 4.

The ion growth rates show the same shape of annual behaviour as DMPS in all size ranges, that is, a maximum during the spring and in the summer and a minimum in the winter. Between February and May 2007 the AIS data coverage was limited due to instrument maintenance and customs problems. During the whole measurement period the growth rate of 3-7 nm ions was highest with the most pronounced annual cycle. The seasonal variation of the growth rate of $1.5-3 \mathrm{~nm}$ ions is the smallest in the three size ranges.
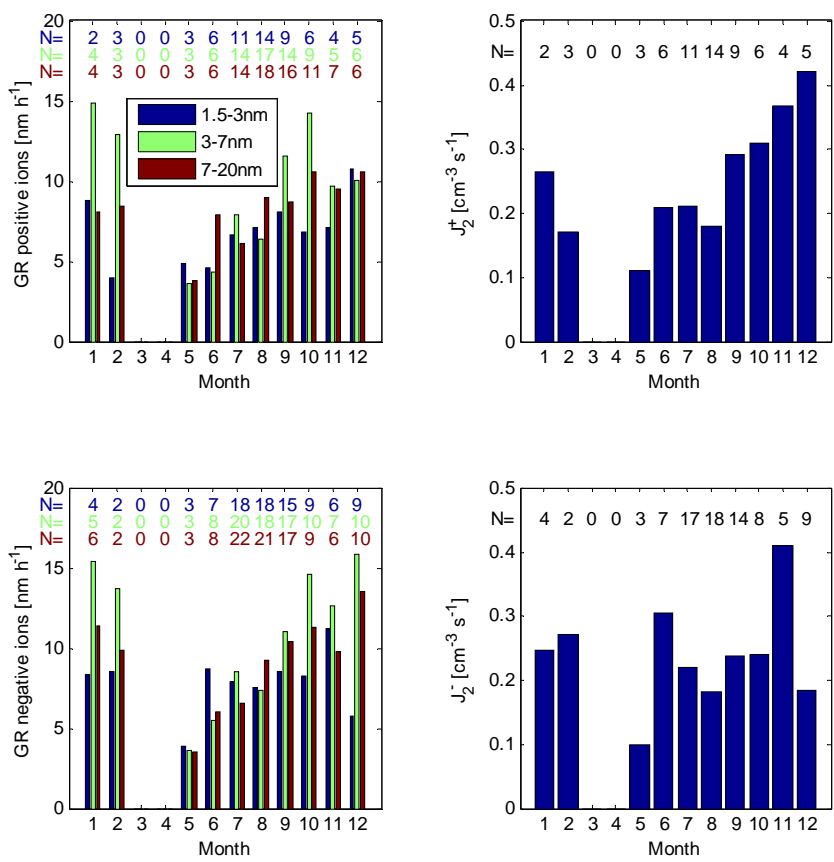

Fig. 5. Monthly averages of positive and negative ion growth and formation rates presented separately for both polarities. The number of events analysed for each month and size range are also shown.

The seasonal behaviour of the $2 \mathrm{~nm}$ ion formation rate, $J_{2}$ (ions), is presented in the right panel of Fig. 4. The $J_{2}$ (ions) does not have much of a seasonal variation. The $J_{2}$ (ions) has been calculated as a sum of positive and negative $J_{2}$ for the days when it was possible to calculate growth rate of $1.5-3 \mathrm{~nm}$ ions. The values of $J_{2}$ (ions) range from 0.07 to $1.6 \mathrm{~cm}^{-3} \mathrm{~s}^{-1}$ with a mean of $0.5 \mathrm{~cm}^{-3} \mathrm{~s}^{-1}$. The fifth term in Eq. (1), which carries the assumption of the neutral cluster concentration being hundred times the measured total ion cluster concentration, is on average 25\% (maximum 90\%) of the sum of the terms 1-4 in Eq. (2). As a sensitivity study, we calculated the $2 \mathrm{~nm}$ ion formation rates for neutral cluster concentrations of 50 and 200 times the ion cluster concentration. For the factor of 50, the total ion formation rate, $J_{2}$ (ions), is on average (median) $15 \%$ higher than for the factor of 100 . For the factor of 200 the $J_{2}$ (ions) is on average (median) $31 \%$ lower, respectively.

The formation rate of neutral $2 \mathrm{~nm}$ clusters from the ionion recombination was on average $0.3 \mathrm{~cm}^{-3} \mathrm{~s}^{-1}$ during new particle formation periods and $0.03 \mathrm{~cm}^{-3} \mathrm{~s}^{-1}$ during the whole period. The upper limit of ion induced nucleation calculated as sum of $J_{2}$ (ions) and ion-ion recombination is on average $0.8 \mathrm{~cm}^{-3} \mathrm{~s}^{-1}$.

Figure 5 presents the growth and formation rates for both polarities separately. The annual behaviour of the polarities does not have significant differences except that the positive ion $J_{2}$ seems to be slightly elevated during the spring. 
Table 2. The mean, minimum and maximum for the growth and formation rates of aerosol particles and ions. The ion growth rates are averaged over both polarities. Total ions indicates the sum of $J_{2}$ (ions) and ion-ion recombination rate and is an approximation of the upper limit of the ion induced nucleation.

\begin{tabular}{lrrrrrr}
\hline & Mean & Median & $25 \%$ & $75 \%$ & Min & Max \\
\hline $\mathrm{GR}_{10-30}\left[\mathrm{~nm} \mathrm{~h}^{-1}\right]$ & 9.7 & 8.9 & 6.3 & 12 & 2.1 & 30 \\
$\mathrm{GR}_{7-20}^{ \pm}\left[\mathrm{nm} \mathrm{h}^{-1}\right]$ & 8.9 & 8.1 & 5.3 & 11 & 2.0 & 29 \\
$\mathrm{GR}_{3-7}^{ \pm}\left[\mathrm{nm} \mathrm{h}^{-1}\right]$ & 9.9 & 8.0 & 5.4 & 12 & 1.3 & 60 \\
$\mathrm{GR}_{1.5-3}^{ \pm}\left[\mathrm{nm} \mathrm{h}^{-1}\right]$ & 7.5 & 6.2 & 4.3 & 9.3 & 1.4 & 31 \\
$J_{10}\left[\mathrm{~cm}^{-3} \mathrm{~s}^{-1}\right]$ & 3.8 & 2.2 & 1.0 & 4.4 & 0.1 & 28 \\
$J_{2}^{-}\left[\mathrm{cm}^{-3} \mathrm{~s}^{-1}\right]$ & 0.2 & 0.2 & 0.1 & 0.3 & 0.02 & 0.9 \\
$J_{2}^{+}\left[\mathrm{cm}^{-3} \mathrm{~s}^{-1}\right]$ & 0.2 & 0.2 & 0.1 & 0.3 & 0.02 & 1.1 \\
$J_{2}$ (ions) $\left[\mathrm{cm}^{-3} \mathrm{~s}^{-1}\right]$ & 0.5 & 0.5 & 0.3 & 0.6 & 0.07 & 1.6 \\
Ion-ion recombination rate $\left[\mathrm{cm}^{-3} \mathrm{~s}^{-1}\right]$ & 0.3 & 0.2 & 0.1 & 0.4 & 0.01 & 1.7 \\
Total ions $\left[\mathrm{cm}^{-3} \mathrm{~s}^{-1}\right]$ & 0.8 & 0.7 & 0.5 & 1.0 & 0.1 & 2.4 \\
\hline
\end{tabular}

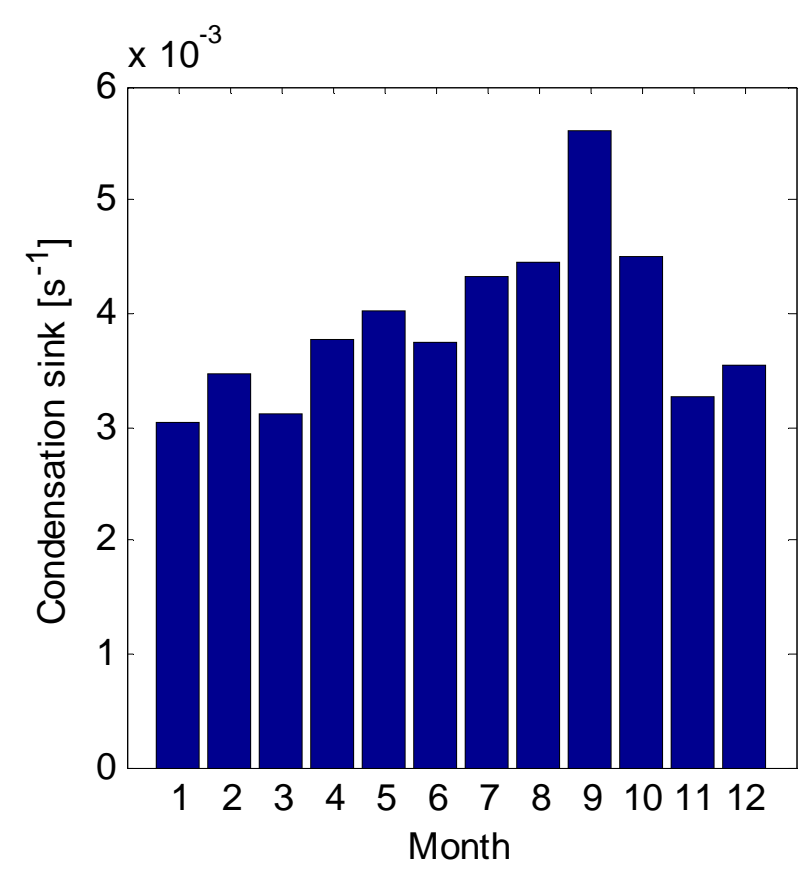

Fig. 6. The monthly averaged condensation sink calculated during 09:30 and 10:30 LT for all days, i.e. including event and non-event days.

To study the seasonal variation in the condensation sink the median CS was calculated daily for the period 09:3010:30, which is one hour later compared to the median hour of the onset of new particle formation events. The CS is clearly elevated during the dry season from May to October with highest values before the beginning of the rainy season in September, Fig. 6. The all time average of the CS is $4.3 \cdot 10^{-3} \mathrm{~s}^{-1}$ during the measurement period, which is in the typical range of CS reported in the literature for rural locations (Kulmala et al., 2005). The lowest CS values have been reported from remote areas, on the order of magnitude of $10^{-4} \mathrm{~s}^{-1}$ (Kulmala et al., 2005). In polluted areas CS is often larger than $10^{-2} \mathrm{~s}^{-1}$ (Kulmala et al., 2005; Hamed et al., 2007; Shen et al., 2011).

The correlation coefficients between $10-30 \mathrm{~nm}$ growth rate and CS and $J_{10}$ and CS are so small, 0.26 for $J_{10}$ and CS and 0.15 for GR and CS, that there is no correlation. The CS was calculated as the median during the period when the new particle formation and growth rates have been calculated. Now that the $J_{10}$ is not correlated with CS and the seasonal cycle of $J_{10}$ does not follow the seasonal cycle of $\mathrm{CS}$, it is unlikely that the CS could explain the observed seasonal variation in formation rates. The same applies for the growth rate: the seasonal cycles do not follow each other and the GR does not correlate with CS and therefore it is unlikely that the CS could explain the observed seasonal variation.

Although the $J_{2}$ (ions) does not have seasonal variation the seasonal cycle of $J_{10}$ could follow from seasonal variation in the nucleation rate of neutral particles, which could not be measured directly. However, the $10-30 \mathrm{~nm}$ growth rate and the sub-10 nm growth rates from the AIS have similar seasonal cycle as $J_{10}$ and hence it is likely that the seasonal difference in $J_{10}$ reflects the growth rate seasonal cycle - with higher growth rate a bigger fraction of the nucleated 1-2 nm particles get to grow to $10 \mathrm{~nm}$ instead of being scavenged by larger particles.

\subsection{Sulphuric acid}

New particle formation frequency was calculated as a function of estimated sulphuric acid concentration by dividing the concentration into logarithmically evenly spaced bins and calculating the frequency of new particle formation and growth - i.e. days classified as IA, IB or II according to Table 1 - in each bin. Also the frequency of non-event days was calculated in each bin. The estimated sulphuric acid concentration was calculated as the median during the first 


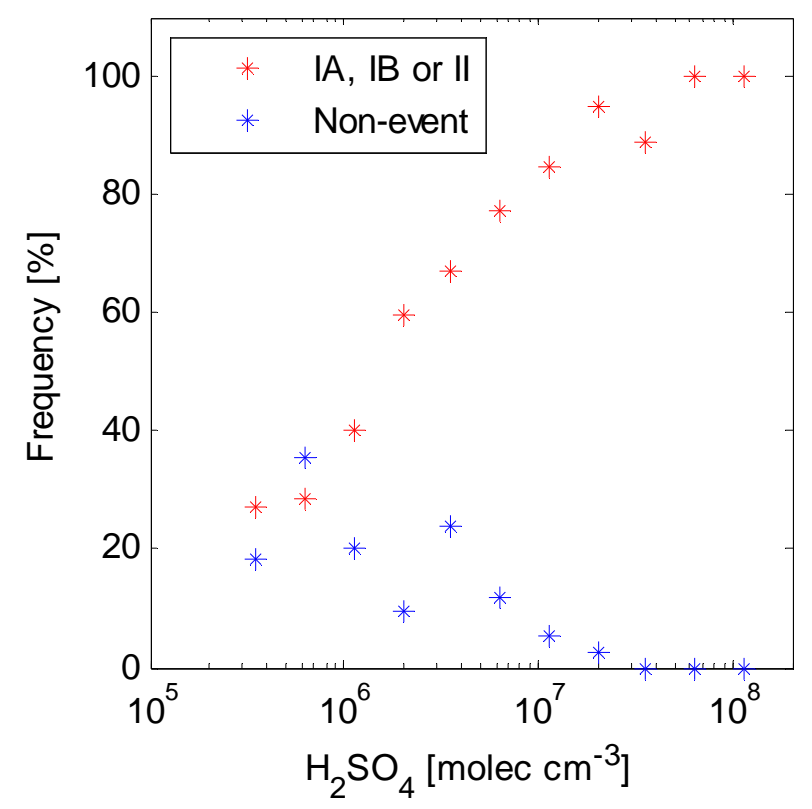

Fig. 7. Frequency of new particle formation and growth days and non-event days as a function of estimated sulphuric acid concentration. The frequency is calculated for logarithmically evenly distributed bins of $\mathrm{H}_{2} \mathrm{SO}_{4}$ concentration.

hour after the observed onset of the formation for event days. For all other days the concentration was calculated as the median during 09:30-10:30, because 09:30 is the median of the observed formation onset times.

The effect of sulphuric acid on new particle formation frequency is illustrated in Fig. 7, which clearly indicates how increasing sulphuric acid concentration increases the frequency of new particle formation and growth and correspondingly decreases the frequency of non-event days. At concentrations higher than $3 \cdot 10^{7}$ molecules $\mathrm{cm}^{-3}$ we do not observe any more non-event days and above $6 \cdot 10^{7}$ molecules $\mathrm{cm}^{-3}$ there are only clear new particle formation and growth days.

The sulphuric acid contribution to the growth rate of aerosol particles was estimated using Eq. (8) in Nieminen et al. (2010) and assuming relative humidity to be $50 \%$. This gives the following relations for sulphuric acid concentration and growth rate: for particles between 1.5 and $3 \mathrm{~nm} 1.15 \cdot 10^{7}$ molecules of $\mathrm{H}_{2} \mathrm{SO}_{4} \mathrm{~cm}^{-3}$ corresponds to $1 \mathrm{~nm} \mathrm{~h}^{-1}$ growth rate, for particles between 3 and $7 \mathrm{~nm} 1.5 \cdot 10^{7}$ molecules of $\mathrm{H}_{2} \mathrm{SO}_{4} \mathrm{~cm}^{-3}$ corresponds to $1 \mathrm{~nm} \mathrm{~h}^{-1}$ growth rate, for particles between 7 and $20 \mathrm{~nm}$ $1.7 \cdot 10^{7}$ molecules of $\mathrm{H}_{2} \mathrm{SO}_{4} \mathrm{~cm}^{-3}$ corresponds to $1 \mathrm{~nm} \mathrm{~h}^{-1}$ growth rate, and for particles between 10 and $30 \mathrm{~nm} 1.8$. $10^{7}$ molecules of $\mathrm{H}_{2} \mathrm{SO}_{4}$ corresponds to $1 \mathrm{~nm} \mathrm{~h}^{-1}$ growth rate.

The estimated sulphuric acid calculated according to Petäjä et al. (2009) has a clear seasonal cycle in Botsalano with maximum during the dry season from May to July, Fig. 8. This cycle is nearly the opposite of the cycle of the

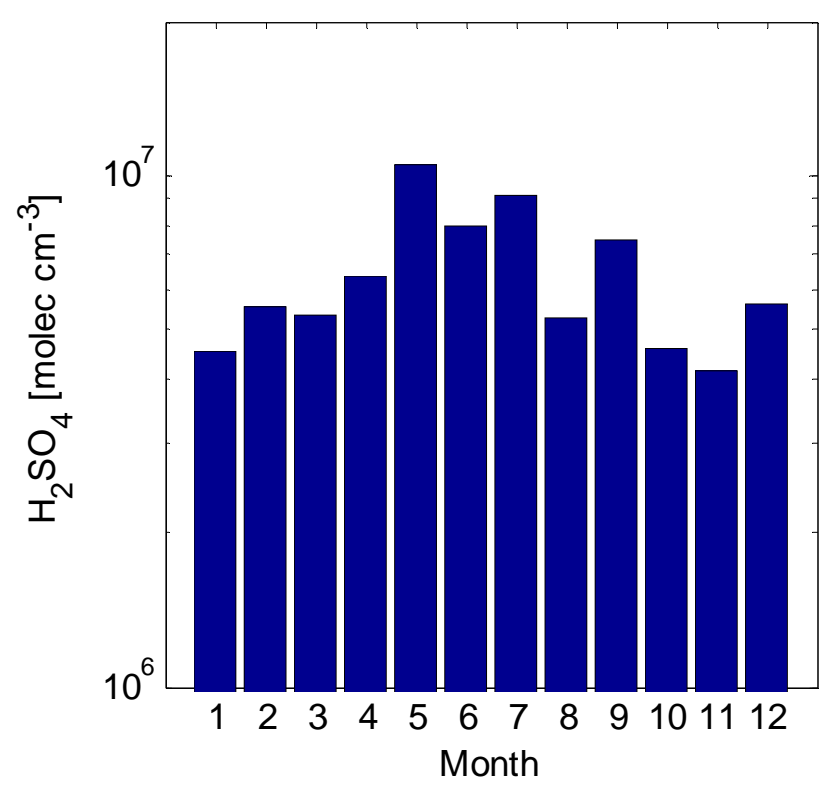

Fig. 8. The monthly averaged estimated $\mathrm{H}_{2} \mathrm{SO}_{4}$ concentration calculated during 08:00 and 14:00 LT.

10-30 $\mathrm{nm}$ aerosol particle growth rates. However, the growth rate calculated from sulphuric acid does not have seasonal cycle, Fig. 9. For this comparison the estimated sulphuric acid values are medians for the period when the growth rates are determined.

The fraction of growth rate explained by the estimated sulphuric acid is decreasing with increasing particle size, which is in line with previous observations from northern hemisphere (Fiedler et al., 2005). On average, the estimated sulphuric acid concentration can explain $25 \%$ of the $1.5-3 \mathrm{~nm}$ growth rate, $16 \%$ of the $3-7 \mathrm{~nm}$ growth rate, $14 \%$ of the $7-$ $20 \mathrm{~nm}$ growth rate and $10 \%$ of the $10-30 \mathrm{~nm}$ growth rate.

\subsection{The effect of air mass history on growth and formation rates}

Figure 10 gives an overview of the meteorological patterns in Botsalano. The anticyclonic flow around the Highveld area (Garstang et al., 1996) is clearly the dominant flow pattern. The semi-permanent continental anticyclone leads to air recirculating over the sub-continent from a week up to 20 days (Tyson et al., 1996). During the dry season this re-circulation together with long-lasting temperature inversion preventing vertical mixing of the air causes the atmosphere to be often layered with alternating layers of clean air and polluted air from industrial sources or from biomass burning (Hobbs, 2003).

The high $\mathrm{SO}_{2}$ emissions from the industry in the Highveld, see discussion in Sect. 2.1, show clearly on the $\mathrm{SO}_{2}$ source area map based on the air mass history, Fig. 11. The emissions are so large that for trajectories passing over the highest 

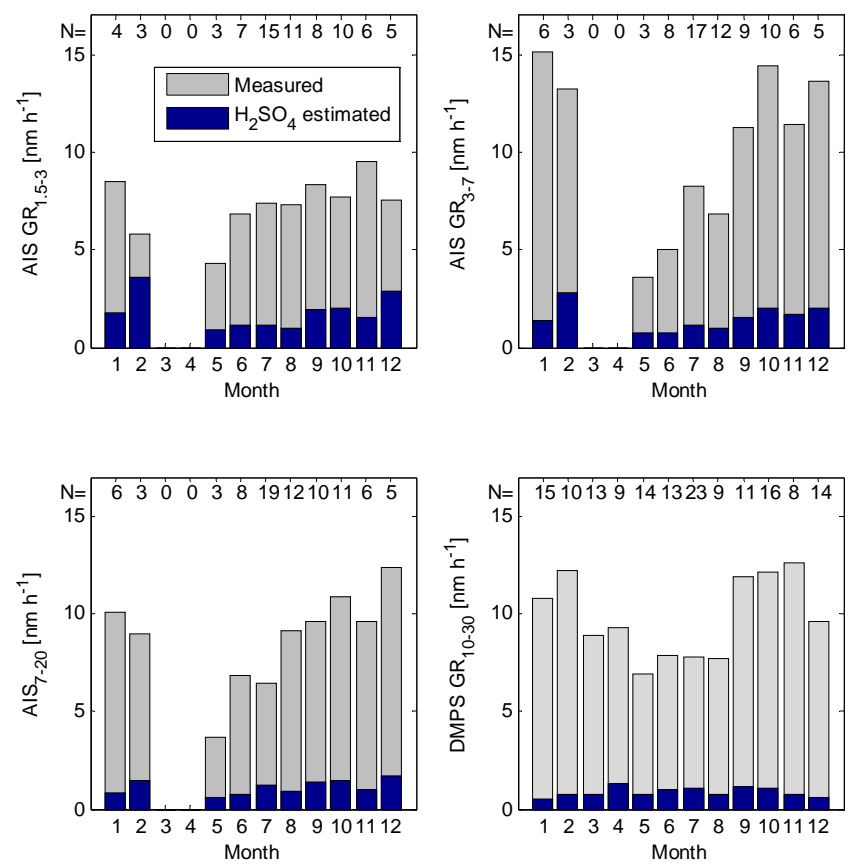

Fig. 9. Observed aerosol particle growth rates and growth rates from the estimated sulphuric acid concentration. The ion growth rates have been averaged over both polarities. The number of events studied is shown for each month and size range.

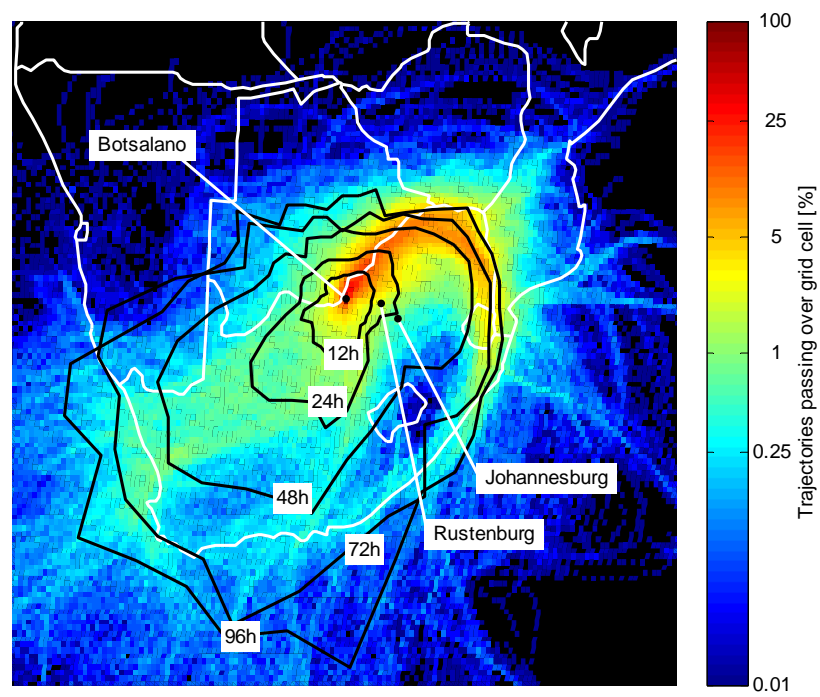

Fig. 10. Back-trajectories in Botsalano. The colour (logarithmic scale) indicates how big a fraction of the back-trajectories passes by each $0.2^{\circ} \times 0.2^{\circ}$ cell on the map. The median position of the back-trajectory at 12, 24, 48, 72 and $96 \mathrm{~h}$ back in each direction from Botsalano is indicated with the black lines.

sources the concentration measured at Botsalano does not represent the concentration in the air mass before Highveld. In fact, if this is not accounted for, there appear artificial sources due south of Botsalano, Fig. 11 left side.

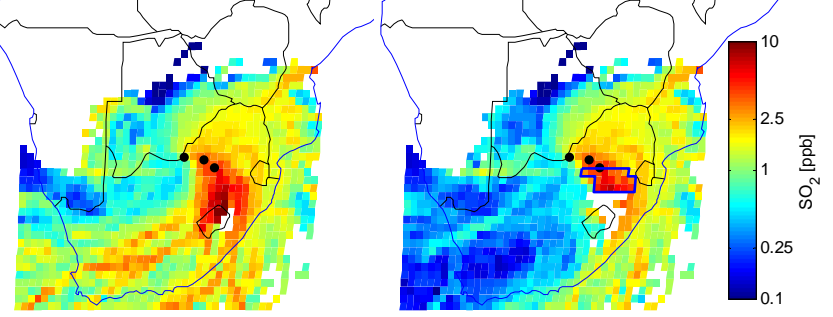

Fig. 11. $\mathrm{SO}_{2}$ source areas. The black dots represent (from left to right) Botsalano, Rustenburg and Johannesburg. The left-hand map presents the source areas with full-length 96-hour back-trajectories. In the right-hand map the trajectories passing over the industrial sources in the Highveld (blue polygon) were cut so that the backtrajectory history before it passed through the polygon was ignored.
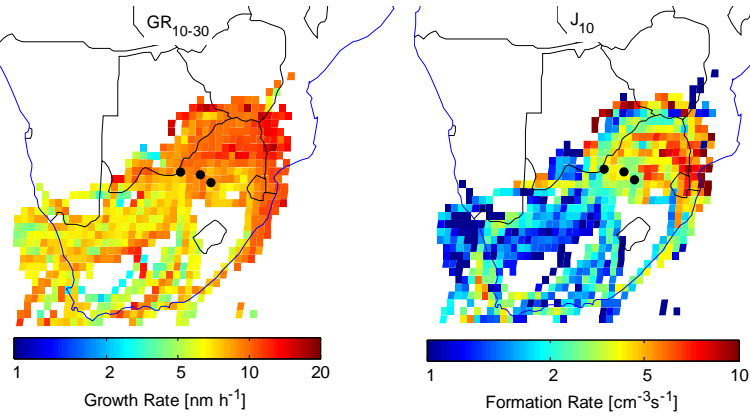

Fig. 12. The source areas of the observed $10-30 \mathrm{~nm}$ growth rate and $10 \mathrm{~nm}$ formation rate from the DMPS measurements. The black dots represent (from left to right) Botsalano, Rustenburg and Johannesburg.

Therefore all back-trajectories passing over the highest sources in the Highveld - the area limited by the blue polygon in Fig. 11 right-hand map - were truncated so that the history of the back trajectory before it passed over Highveld was left out from the analysis. This removes the artificial sources in the left-hand map in Fig. 11 and results in the right-hand map. This map compares well with the $\mathrm{SO}_{2}$ emission inventory, Fig. 1. Sources of $\mathrm{SO}_{2}$ on the south-western coast over $1000 \mathrm{~km}$ away from Botsalano (in Western Cape) are not visible, but otherwise the $\mathrm{SO}_{2}$ source areas follow the shape of the emission inventory. The same cut was applied to air mass history studies of aerosol particles and other variables as well.

The highest aerosol particle formation and growth rates determined from the DMPS measurements show up in the north easterly directions from the Botsalano game reserve, Fig. 12. This is the region where the VOC emission inventory by Otter (2004) presents the highest monoterpenes emissions. The semi-arid Karoo region southwest of Botsalano produces slightly lower growth rates and clearly lower formation rates. The difference between the Karoo region and the area north and east from Botsalano originates in the 


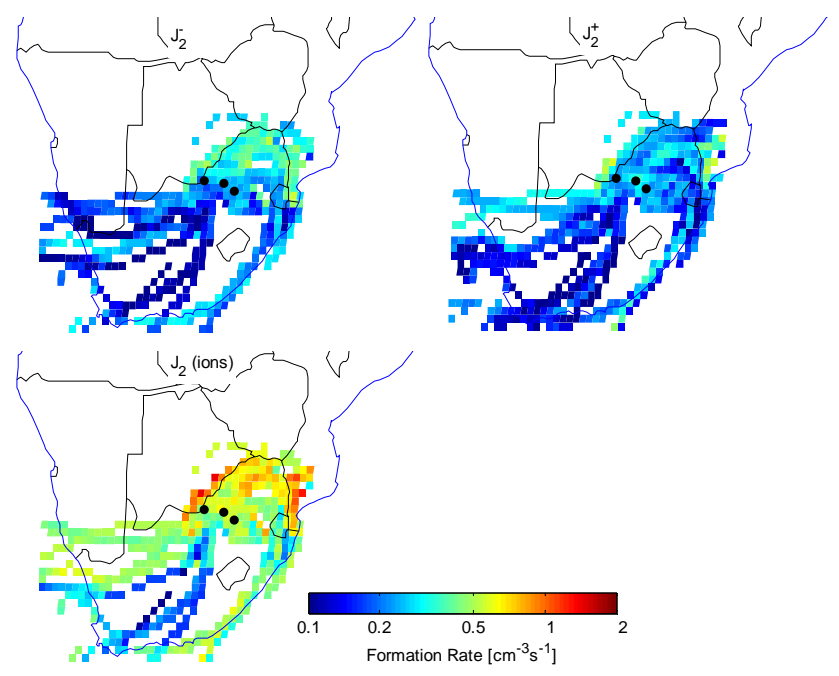

Fig. 13. The source areas of the $2 \mathrm{~nm}$ ion formation rates for positive and negative ions separately and the total $2 \mathrm{~nm}$ ion formation rate. The black dots represent (from left to right) Botsalano, Rustenburg and Johannesburg.

different sources: in Karoo both anthropogenic sources (see discussion in Sect. 2.1) and biological activity (Friedl et al., 2002) are small and hence the formation and growth rates are low. The Highveld and the Rustenburg-Johannesburg area east of Johannesburg do not stand out as high growth or formation rate sources even though the highest $\mathrm{SO}_{2}$ concentrations originate in these areas, Fig. 11.

The $2 \mathrm{~nm}$ ion formation rates show the same kind of pattern as the $10 \mathrm{~nm}$ aerosol particle formation rate, Fig. 13 . The highest ion formation rates originate in the north-eastern Limpopo valley whereas the south-western Karoo direction yields clearly lower formation rates. The areas with most anthropogenic activities show formation rates slightly below average.

The ion growth rates are also generally smaller when air masses are coming from the south-western Karoo direction and higher for the north-eastern direction, Fig. 14. The 1.5$3 \mathrm{~nm}$ negative ion growth rate, however, has a maximum at the Rustenburg-Johannesburg area and the $3-7 \mathrm{~nm}$ growth rates of both polarities show slightly elevated values for the Rustenburg-Johannesburg area. The difference in $1.5-3 \mathrm{~nm}$ growth rates may be related to ion chemistry favouring condensation of sulphuric acid on negative ions.

The $7-20 \mathrm{~nm}$ ion growth rates follow the same pattern as the $10-30 \mathrm{~nm}$ aerosol particle growth rates with highest growth rates originating in the north-eastern direction and the lowest from the south-western direction.

The condensation sink source areas have same kind of general pattern as the aerosol particle formation and growth rates, reflecting the different sources in the Karoo and Highveld. The south-western Karoo region produces a very low condensation sink whereas the highest values of CS originate

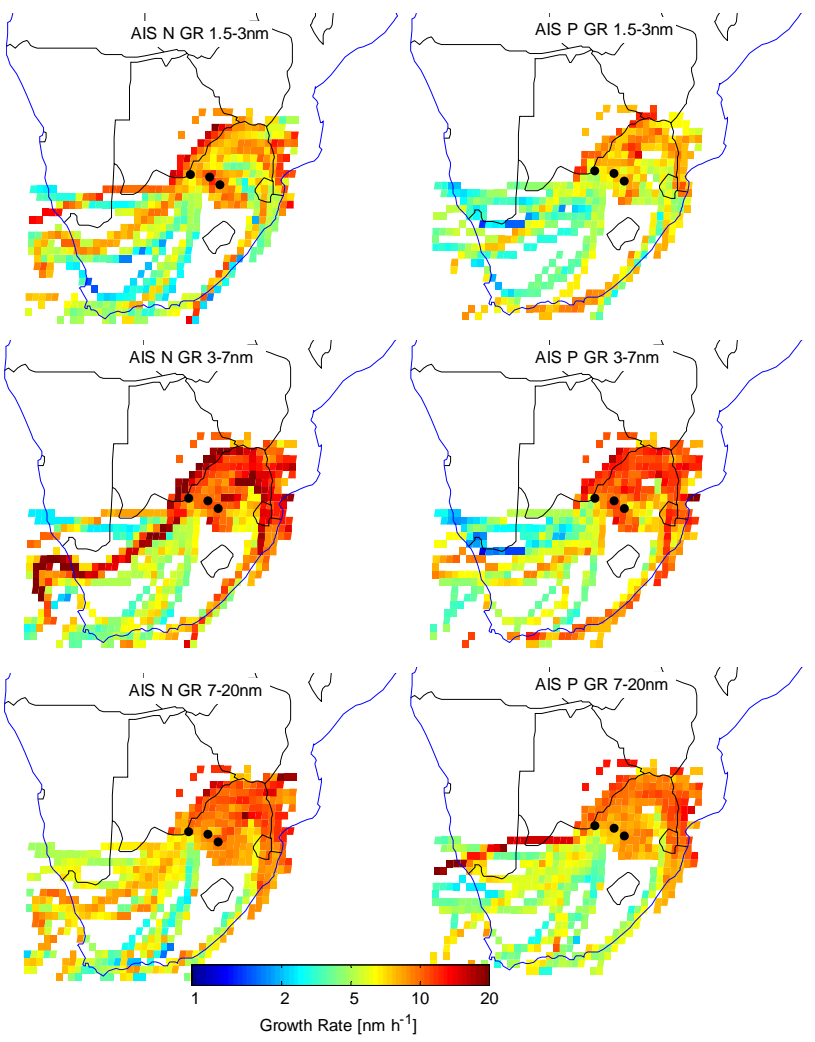

Fig. 14. The source areas of the ion growth rates for size ranges 1.5 $3 \mathrm{~nm}, 3-7 \mathrm{~nm}$ and $7-20 \mathrm{~nm}$ from the AIS measurements. The black dots on the map represent (from left to right) Botsalano, Rustenburg and Johannesburg.

in the northern and eastern directions. The highest CS values come, however, from the Highveld region, Fig. 15, not the north eastern Limpopo valley where the highest growth rates originate.

The source area distribution of the estimated sulphuric acid is presented in Fig. 16. The highest concentrations originate quite naturally in the areas of highest $\mathrm{SO}_{2}$ emissions, i.e. the Highveld region east of Johannesburg. In the southwestern direction the concentrations are the lowest.

The contribution of sulphuric acid to the growth rate is largest for all size ranges for air masses originating in the Highveld region and smallest for the south-western direction, Fig. 17. The decrease in the relative significance of $\mathrm{H}_{2} \mathrm{SO}_{4}$ with increasing size is clearly seen. The estimated sulphuric acid can explain over $25 \%$ of the $10-30 \mathrm{~nm}$ growth rate only for air masses coming from the Johannesburg-Highveld region whereas for the smallest size range, $1.5-3 \mathrm{~nm}$, it can explain a major fraction of the observed growth also for air masses coming from the north-eastern direction and occasionally also from the south-western direction. However, one should keep in mind that the sulphuric acid concentration is only indicative as it is estimated based on a proxy developed for a different environment. 


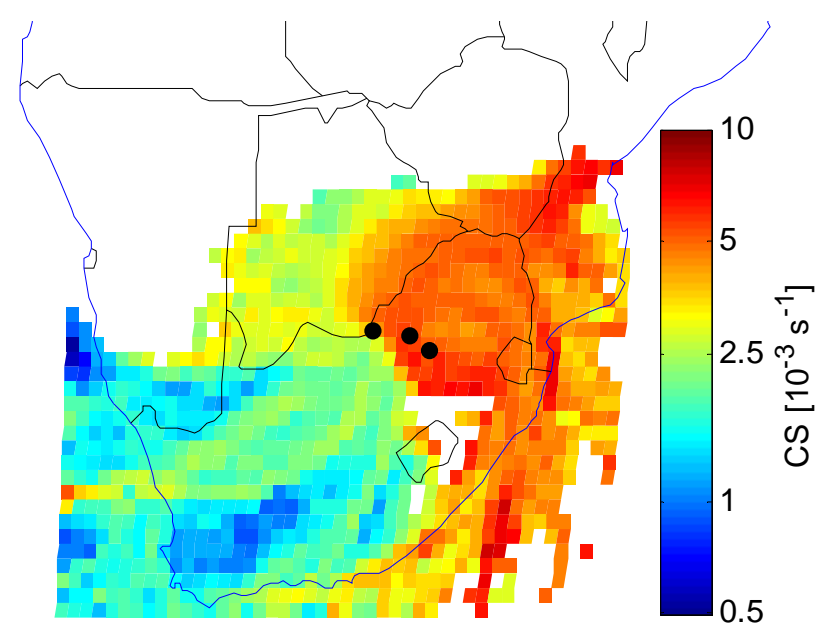

Fig. 15. The source areas of condensation sink. The black dots on the map represent (from left to right) Botsalano, Rustenburg and Johannesburg.

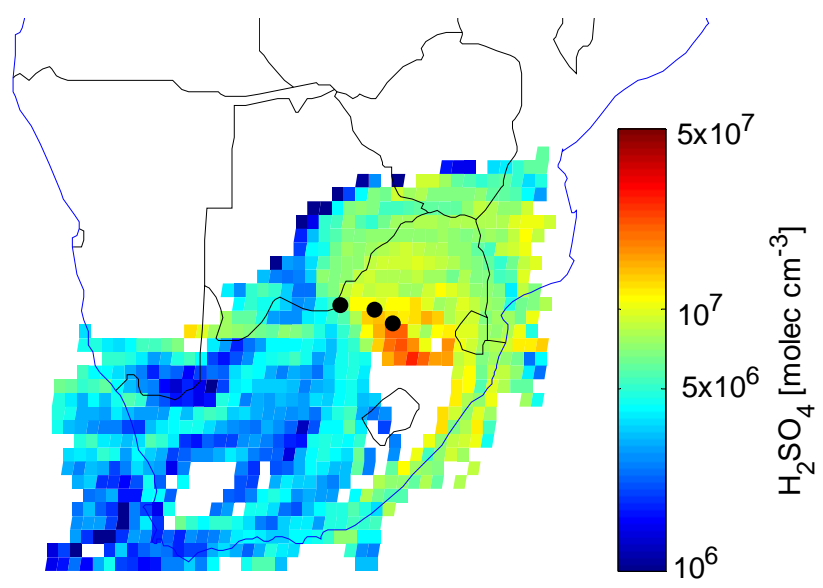

Fig. 16. The source areas of the estimated $\mathrm{H}_{2} \mathrm{SO}_{4}$ concentration. The black dots represent (from left to right) Botsalano, Rustenburg and Johannesburg.

\section{Conclusions}

We have presented here the first detailed analysis on new particle formation in a semi-clean savannah environment based on one and half years of continuous measurements of air ions, aerosol particle size distribution, trace gases and basic meteorological variables. New particle formation and growth was observed on $69 \%$ of the days, which is the highest frequency reported from boundary layer so far. In addition to this, bursts of intermediate ions were observed on $14 \%$ of the days. Only $6 \%$ of days could be classified as clear nonevent days. The new particle formation frequency was found to increase with increasing sulphuric acid concentration estimated with a proxy developed by Petäjä et al. (2009). With estimated sulphuric acid concentrations above $3 \cdot 10^{7} \mathrm{~cm}^{-3}$

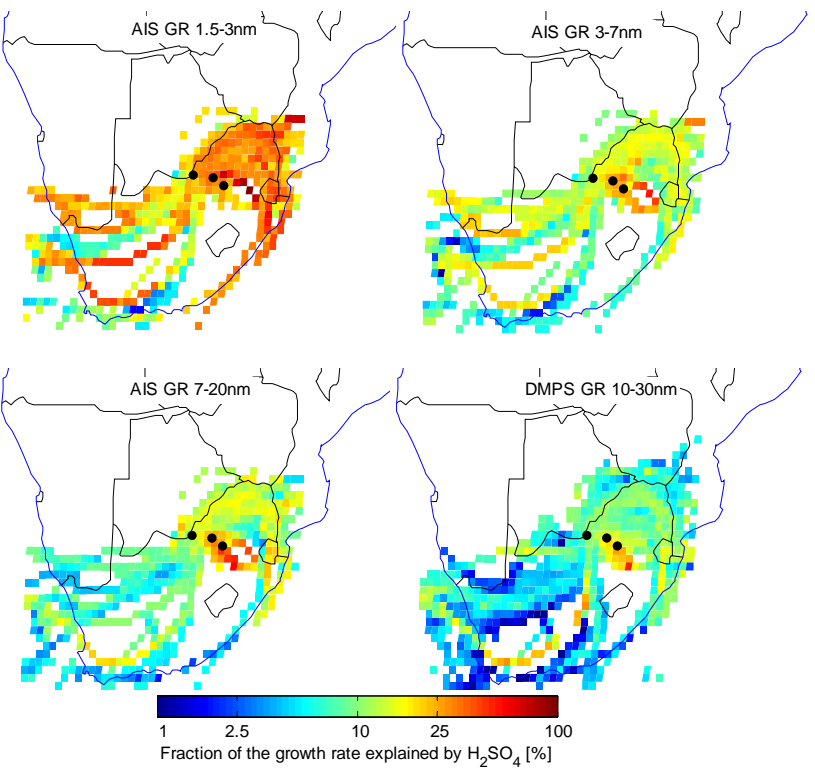

Fig. 17. The source areas of the fraction of growth rate explained by estimated $\mathrm{H}_{2} \mathrm{SO}_{4}$. The black dots represent (from left to right) Botsalano, Rustenburg and Johannesburg.

no non-event days were any more observed. The new particle formation frequency did not depend on the season.

The $10 \mathrm{~nm}$ particle formation rate and the growth rates, however, did have a clear seasonal dependency with minimum during the southern hemisphere winter and maxima in spring and late summer, suggesting biological activity to contribute significantly to the growth of the particles. The annual cycles of the 3-7 nm and 7-20 nm ion growth rates and 10$30 \mathrm{~nm}$ aerosol particle growth rates were significantly more pronounced than the cycle of the 1.5-3 nm ion growth rates. The $1.5-3 \mathrm{~nm}$ growth rate was also the smallest of the observed growth rates with mean of $7.5 \mathrm{~nm} \mathrm{~h}^{-1}$, while the mean $3-7 \mathrm{~nm}, 7-20 \mathrm{~nm}$ and $10-30 \mathrm{~nm}$ growth rates were 9.9, 8.9 and $9.7 \mathrm{~nm} \mathrm{~h}^{-1}$, respectively. The mean $10 \mathrm{~nm}$ formation rate was $3.8 \mathrm{~cm}^{-3} \mathrm{~s}^{-1}$. The formation and growth rates are among the highest reported from continental locations (Kulmala et al., 2004; Kulmala and Kerminen, 2008).

The $2 \mathrm{~nm}$ ion formation rate, on the other hand, did not have a seasonal variation, but stayed rather constant throughout the measurement period. The upper limit of ion formation, the sum of $J_{2}$ (ions) and ion-ion recombination rate, was on average $0.8 \mathrm{~cm}^{-3} \mathrm{~s}^{-1}$. However, as the detection limit of neutral particles was $10 \mathrm{~nm}$, the ratio of ion formation to neutral particle formation cannot be quantitatively estimated.

The growth rate estimated by sulphuric acid did not have seasonal variation. However, the fraction of growth rate explained by estimated sulphuric acid had a clear dependency on the size range of the growth rate. The contribution of sulphuric acid on the growth rate decreases with increasing particle size: for the $1.5-3 \mathrm{~nm}$ size range the estimated sulphuric 
acid can explain on average $25 \%$ of the growth rate, but for the $10-30 \mathrm{~nm}$ size range only $10 \%$.

Also the source areas of the observed growth rates showed a clear dependency on the size range of the growth rate. The highest negative $1.5-3 \mathrm{~nm}$ ion growth rates originated in the same area as the highest $\mathrm{SO}_{2}$ and estimated sulphuric acid concentrations whereas the highest $3-7 \mathrm{~nm}$ and $7-20 \mathrm{~nm}$ ion and $10-30 \mathrm{~nm}$ aerosol particle growth rates originated in the same region where the VOC emission inventory by Otter (2004) presents the highest monoterpene emissions.

The three different approaches used to study the origin of the observed high growth rates - seasonal variation, sulphuric acid estimates and source areas - all indicate that sulphuric acid alone is not enough to explain the growth. The seasonal variation in the growth rate suggests biological activity to contribute significantly to the growth; furthermore, the airmass history study connects highest growth rates to the areas of highest biogenic VOC emissions emphasizing the importance of biogenic VOC's in the growth. On the other hand, the occurrence of new particle formation and growth was strongly dependent on sulphuric acid and the contribution of sulphuric acid to the growth immediately after nucleation was significant, which implies that the formation and growth processes are to a large degree independent of each other.

Acknowledgements. The authors acknowledge the financial support by the Academy of Finland under the projects Air pollution in Southern Africa (APSA) (project number 117505) and Atmospheric monitoring capacity building in Southern Africa (project number 132640) and by the European Commission 6th Framework program project EUCAARI, contract no 036833-2 (EUCAARI). The authors thank Head of Botsalano game reserve, M. Khukhela and the game reserve employees for their kind and invaluable help during our measurements. In addition, the authors are grateful to M. Jokinen and E. Sjöberg for their help to organizing the project.

Edited by: E. Swietlicki

\section{References}

Air Resources Laboratory, Gridded Meteorological Data Archives, available at: http://www.arl.noaa.gov/archives.php, 2009.

Anderson, H. R.: Air pollution and mortality: A history, Atmos. Environ., 43, 142-152, 2009

Dal Maso, M., Kulmala, M., Riipinen, I., Wagner, R., Hussein, T., Aalto, P. P., and Lehtinen, K. E. J.: Formation and growth of fresh atmospheric aerosols: eight years of aerosol size distribution data from SMEAR II, Hyytiälä, Finland., Boreal Environ. Res., 10, 323-336, 2005.

Draxler, R. R. and Hess, G. D.: Description of the HYSPLIT_4 Modelling System, NOAA Technical Memorandum ERL ARL224, 2004.

Fiedler, V., Dal Maso, M., Boy, M., Aufmhoff, H., Hoffmann, J., Schuck, T., Birmili, W., Hanke, M., Uecker, J., Arnold, F., and Kulmala, M.: The contribution of sulphuric acid to atmospheric particle formation and growth: a comparison between boundary layers in Northern and Central Europe, Atmos. Chem. Phys., 5, 1773-1785, doi:10.5194/acp-5-1773-2005, 2005.

Fleming, G. and van der Merwe, M.: Spatial disaggregation of greenhouse gas emissions inventory data for Africa south of the equator, available at: http://gis.esri.com/library/userconf/proc00/ professional/papers/PAP896/p896.htm, 2002.

Forster, P., Ramaswamy, V., Artaxo, P., Berntsen, T., Betts, R., Fahey, D. W., Haywood, J., Lean, J., Lowe, D. C., Myhre, G., Nganga, J., Prinn, R., Raga, G., Schulz, M., and Van Dorland, R.: Changes in Atmospheric Constituents and in Radiative Forcing, In: Climate Change 2007: The Physical Science Basis. Contribution of Working Group I to the Fourth Assessment Report of the Intergovernmental Panel on Climate Change, edited by: Solomon, S., Qin, D., Manning, M., Chen, Z., Marquis, M., Averyt, K. B., Tignor, M., and Miller, H. L., Cambridge University Press, Cambridge, United Kingdom and New York, NY, USA, 136, 2007.

Friedl, M. A., McIver, D. K., Hodges, J. C. F., Zhang, X. Y., Muchoney, D., Strahler, A. H., Woodcock, C. E., Gopal, S., Schneider, A., Cooper, A., Baccini, A., Gao, F., and Schaaf, C.: Global land cover mapping from MODIS: algorithms and early results, Remote Sens. Environ., 83, 287-302, doi:10.1016/S00344257(02)00078-0, 2002.

Garstang, M., Tyson, M., Swap, R., Edwards, M., Kållberg, P., and Lindesay, J. A.: Horizontal and vertical transport of air over southern Africa, J. Geophys. Res., 101, 23721-23736, 1996.

Güenther, A., Otter, L., Zimmermann, P., Greenberg, J., Scholes, R., and Scholes, M.: Biogenic hydrocarbon emissions from Southern African savannas, J. Geophys. Res., 101, 25859-25865, 1996.

Hamed, A., Joutsensaari, J., Mikkonen, S., Sogacheva, L., Dal Maso, M., Kulmala, M., Cavalli, F., Fuzzi, S., Facchini, M. C., Decesari, S., Mircea, M., Lehtinen, K. E. J., and Laaksonen, A.: Nucleation and growth of new particles in Po Valley, Italy, Atmos. Chem. Phys., 7, 355-376, doi:10.5194/acp-7-355-2007, 2007.

Hand, J. L. and Malm, W.C.: Review of aerosol mass scattering efficiencies from ground-based measurements since 1990, J. Geophys. Res., 112, D16203, doi:10.1029/2007JD008484, 2007.

Hirsikko, A., Laakso, L., Hõrrak, U., Aalto, P. P., Kerminen, V.-M., and Kulmala, M.: Annual and size dependent variation of growth rates and ion concentration in boreal forest, Boreal Environ. Res., 10, 357-369, 2005.

Hirsikko, A., Bergman, T., Laakso, L., Dal Maso, M., Riipinen, I., Hõrrak, U., and Kulmala, M.: Identification and classification of the formation of intermediate ions measured in boreal forest, Atmos. Chem. Phys., 7, 201-210, doi:10.5194/acp-7-201-2007, 2007.

Hobbs, P. V.: Clean air slots amid dense atmospheric pollution in Southern Africa, J. Geophys. Res., 108, 8490, doi:10.1029/2002JD002156, 2003.

Hoppel, W. A.: Determination of the aerosol size distribution from the mobility distribution of the charged fraction of aerosols, J. Aerosol Sci., 9, 41-54, 1978.

Iida, K., Stolzenburg, M. R., McMurry, P. H., and Smith, J. N.: Estimating nanoparticle growth rates from sizedependent charged fractions: Analysis of new particle formation events in Mexico City, J. Geophys. Res., 113, D05207, doi:10.1029/2007JD009260, 2008. 
Jokinen, V. and Mäkelä, J. M.: Closed loop arrangement with critical orifice for DMA sheath/excess flow system, J. Aerosol Sci., 28, 643-648, 1997.

Kulmala, M. and Kerminen, V.-M.: On the formation and growth of atmospheric nanoparticles, Atmos. Res., 90, 132-150, 2008.

Kulmala, M., Vehkamäki, H., Petäjä, T., Dal Maso, M., Lauri, A., Kerminen, V.-M., Birmili, W., and McMurry, P. H.: Formation and growth rates of ultrafine atmospheric particles: A review of observations, J. Aerosol Sci., 35, 143-176, 2004.

Kulmala, M., Riipinen, I., Sipilä, M., Manninen, H. E., Petäjä, T., Junninen, H., Dal Maso, M., Mordas, G., Mirme, A., Vana, M., Hirsikko, A., Laakso, L., Harrison, M.M., Hanson, I., Leung, C., Lehtinen, K. E. J., and Kerminen, V.-M.: Toward direct measurement of atmospheric nucleation, Science, 318, 89-92, 2007.

Kulmala, M., Asmi, A., Lappalainen, H. K., Carslaw, K. S., Pöschl, U., Baltensperger, U., Hov, Ø., Brenquier, J.-L., Pandis, S. N., Facchini, M. C., Hansson, H.-C., Wiedensohler, A., and O'Dowd, C. D.: Introduction: European Integrated Project on Aerosol Cloud Climate and Air Quality interactions (EUCAARI) - integrating aerosol research from nano to global scales, Atmos. Chem. Phys., 9, 2825-2841, doi:10.5194/acp-9-2825-2009, 2009.

Laakso, L., Koponen, I. K., Mönkkönen, P., Kulmala, M., Kerminen, V.-M., Wehner, B., Wiedensohler, A., Wu, Z., and Hu, M.: Aerosol particles in the developing world; a comparison between New Delhi in India and Beijing in China, Water Air Soil Poll., 173, 5-20, 2006.

Laakso, L., Laakso, H., Aalto, P. P., Keronen, P., Petäjä, T., Nieminen, T., Pohja, T., Siivola, E., Kulmala, M., Kgabi, N., Molefe, M., Mabaso, D., Phalatse, D., Pienaar, K., and Kerminen, V.-M.: Basic characteristics of atmospheric particles, trace gases and meteorology in a relatively clean Southern African Savannah environment, Atmos. Chem. Phys., 8, 4823-4839, doi:10.5194/acp-8-4823-2008, 2008.

Manninen, H. E., Petäjä, T., Asmi, E., Riipinen, I., Nieminen, T., Mikkilä, J., Hõrrak, U., Mirme, A., Mirme, S., Laakso, L., Kerminen, V.-M., and Kulmala, M.: Long-term field measurements of charged and neutral clusters using Neutral cluster and Air Ion Spectrometer (NAIS), Boreal Environ. Res., 14, 591-605, 2009a.

Manninen, H. E., Nieminen, T., Riipinen, I., Yli-Juuti, T., Gagné, S., Asmi, E., Aalto, P. P., Petäjä, T., Kerminen, V.-M., and Kulmala, M.: Charged and total particle formation and growth rates during EUCAARI 2007 campaign in Hyytiälä, Atmos. Chem. Phys., 9, 4077-4089, 2009b,

http://www.atmos-chem-phys.net/9/4077/2009/.

Manninen, H. E., Nieminen, T., Asmi, E., Gagné, S., Häkkinen, S., Lehtipalo, K., Aalto, P., Vana, M., Mirme, A., Mirme, S., Hõrrak, U., Plass-Dülmer, C., Stange, G., Kiss, G., Hoffer, A., Tör, N., Moerman, M., Henzing, B., de Leeuw, G., Brinkenberg, M., Kouvarakis, G. N., Bougiatioti, A., Mihalopoulos, N., O'Dowd, C., Ceburnis, D., Arneth, A., Svenningsson, B., Swietlicki, E., Tarozzi, L., Decesari, S., Facchini, M. C., Birmili, W., Sonntag, A., Wiedensohler, A., Boulon, J., Sellegri, K., Laj, P., Gysel, M., Bukowiecki, N., Weingartner, E., Wehrle, G., Laaksonen, A., Hamed, A., Joutsensaari, J., Petäjä, T., Kerminen, V.-M., and Kulmala, M.: EUCAARI ion spectrometer measurements at 12 European sites - analysis of new particle formation events, Atmos. Chem. Phys., 10, 7907-7927, doi:10.5194/acp-10-79072010, 2010 .
Merikanto, J., Spracklen, D. V., Mann, G. W., Pickering, S. J., and Carslaw, K. S.: Impact of nucleation on global CCN, Atmos. Chem. Phys., 9, 8601-8616, doi:10.5194/acp-9-8601-2009, 2009.

Mirme, A., Tamm, E., Mordas, G., Vana, M., Uin, J., Mirme, S., Bernotas, T., Laakso, L., Hirsikko, A., and Kulmala, M.: A widerange multi-channel Air Ion Spectrometer, Boreal Environ. Res., 12, 247-264, 2007.

Mäkelä, J. M., Aalto, P., Jokinen, V., Pohja, T., Nissinen, A., Palmroth, S., Markkanen, T., Seitsonen, K., Lihavainen, H., and Kulmala, M.: Observations of ultrafine aerosol particle formation and growth in boreal forest, Geophys. Res. Lett., 24, 1219-1222, 1997.

Nieminen, T., Lehtinen, K. E. J., and Kulmala, M.: Sub-10 nm particle growth by vapor condensation - effects of vapor molecule size and particle thermal speed, Atmos. Chem. Phys., 10, 9773 9779, doi:10.5194/acp-10-9773-2010, 2010.

Otter, L.: SAFARI 2000 Estimated BVOC Emissions for Southern African Land Cover Types. Data Set, available at: http://daac. ornl.gov/, from Oak Ridge National Laboratory Distributed Active Archive Centre, Oak Ridge, Tennessee, USA, 2004.

Otter, L. B., Güenther A., and Greenberg, J.: Seasonal and spatial variations in biogenic hydrocarbon emissions from southern African savannas and woodlands, Atmos. Environ., 36, 42654275, 2002.

Otter, L., Güenther, A., Wiedinmyer, C., Fleming, G., Harley, P., and Greenberg, J.: Spatial and temporal variations in biogenic volatile organic compound emissions for Africa South of equator, J. Geophys. Res., 108, 8505, doi:10.1029/2002JD002609, 2003.

Petäjä, T., Mauldin, III, R. L., Kosciuch, E., McGrath, J., Nieminen, T., Paasonen, P., Boy, M., Adamov, A., Kotiaho, T., and Kulmala, M.: Sulfuric acid and $\mathrm{OH}$ concentrations in a boreal forest site, Atmos. Chem. Phys., 9, 7435-7448, doi:10.5194/acp9-7435-2009, 2009.

Petäjä, T., Vakkari, V., Pohja, T., Nieminen, T., Laakso, H., Aalto, P. P., Keronen, P., Siivola, E., Kerminen, V.-M., Kulmala, M., and Laakso, L.: Transportable air quality and atmospheric monitoring trailer for developing countries: design, instruments and verification, Boreal Environment Research, submitted, 2010.

Piketh, S., van Nierop, M., Rautenbach, C., Walton, N., Ross, K., Holmes, S., and Richards, T.: Rustenburg Local Muncipality Air Quality Management Plan, Palace consulting engineers ltd., Republic of South Africa, 2005.

Pope, C. A. and Dockery, D. W.: Health effects of fine particulate air pollution: lines that connect, J. Air Waste Manage., 56, 709742, 2006.

Riddle, E. E., Voss, P. B., Stohl, A., Holcomb, D., Maczka, D., Washburn, K., and Talbot, R. W.: Trajectory model validation using newly developed altitude-controlled balloons during the International Consortium for Atmospheric Research on Transport and Transformations 2004 campaign, J. Geophys. Res., 111, D23S57, doi:10.1029/2006JD007456, 2006.

Shen, X. J., Sun, J. Y., Zhang, Y. M., Wehner, B., Nowak, A., Tuch, T., Zhang, X. C., Wang, T. T., Zhou, H. G., Zhang, X. L., Dong, F., Birmili, W., and Wiedensohler, A.: First long-term study of particle number size distributions and new particle formation events of regional aerosol in the North China Plain, Atmos. Chem. Phys., 11, 1565-1580, doi:10.5194/acp-11-15652011, 2011. 
Spracklen, D. V., Carslaw, K. S., Kulmala, M., Kerminen, V.-M., Sihto, S.-L., Riipinen, I., Merikanto, J., Mann, G. W., Chipperfield, M. P., Wiedensohler, A., Birmili, W., and Lihavainen, H.: Contribution of particle formation to global cloud condensation nuclei concentrations, Geophys. Res. Lett., 35, L06808, doi:10.1029/2007GL033038, 2008.

Stohl, A.: Computation, accuracy and application of trajectories - a review and bibliography, Atmos. Environ., 32, 947-966, 1998.

Swap, R. J., Annegarn, H. J., Suttles, J. T., King, M. D., Platnick, S., Privette, J. L., and Scholes, R. J.: Africa burning: A thematic analysis of the Southern African Regional Science Initiative (SAFARI 2000), J. Geophys. Res., 108, 8465, doi:10.1029/2003JD003747, 2003.

Tammet, H. and Kulmala, M.: Simulation tool for atmospheric aerosol nucleation bursts, J. Aerosol Sci., 36, 173-196, 2005.

Thermo Environmental Instruments, Inc.: Instruction Manual for Model 43S High Sensitive Pulsed Fluorescence SO2 Analyzer, Thermo Environ. Instruments, Inc., Franklin, MA, USA, 1992.

Tyson, P. D., Garstang, M., and Swap, R.: Large-scale recirculation of Air over Southern Africa, J. Appl. Meteorol., 35, 2218-2236, 1996.
Vana, M., Ehn, M., Petäjä, T., Vuollekoski, H., Aalto, P. P., de Leeuw, G., Ceburnis, D., O'Dowd, C. D., and Kulmala, M.: Characteristic features of air ions at Mace Head on the west coast of Ireland, Atmos. Res., 90, 278-286, 2008.

Vartiainen, E., Kulmala, M., Ehn, M., Hirsikko, A., Junninen, H., Petäjä, T., Sogacheva, L., Kuokka, S., Hillamo, R., Skorokhod, A., Belikov, I., Elansky, N., and Kerminen, V.-M.: Ion and particle number concentrations and size distributions along the TransSiberian railroad, Boreal Env. Res., 12, 375-396, 2007.

Venzac, H., Sellegri, K., Villani, P., Picard, D., and Laj, P.: Seasonal variation of aerosol size distributions in the free troposphere and residual layer at the puy de Dôme station, France, Atmos. Chem. Phys., 9, 1465-1478, doi:10.5194/acp-9-1465-2009, 2009.

Yli-Juuti, T., Riipinen, I., Aalto, P. P., Nieminen, T., Maenhaut, W., Janssens, I. A., Claeys, M., Salma, I., Ocskay, R., Hoffer, A., Imre, K., and Kulmala, M.: Characteristics of new particle formation events and cluster ions at K-puszta, Hungary, Boreal Environ. Res., 14, 683-698, 2009. 